Texas A\&M University-San Antonio

Digital Commons @ Texas A\&M University- San Antonio

\title{
The Invisible Scholar: Authors of Legal Scholarship in Criminology and Criminal Justice Journals
}

\author{
Brenda I. Rowe \\ Texas A\&M University-San Antonio, Brenda.Rowe@tamusa.edu \\ Wesley S. McCann \\ Washington State University \\ Craig Hemmens \\ Washington State University
}

Follow this and additional works at: https://digitalcommons.tamusa.edu/crim_faculty

Part of the Criminology and Criminal Justice Commons, and the Legal Writing and Research Commons

\section{Repository Citation}

Rowe, Brenda I.; McCann, Wesley S.; and Hemmens, Craig, "The Invisible Scholar: Authors of Legal Scholarship in Criminology and Criminal Justice Journals" (2018). Criminology and Criminal Justice Faculty Publications. 6.

https://digitalcommons.tamusa.edu/crim_faculty/6

This Article is brought to you for free and open access by the College of Arts and Sciences at Digital Commons @ Texas A\&M University- San Antonio. It has been accepted for inclusion in Criminology and Criminal Justice Faculty Publications by an authorized administrator of Digital Commons @ Texas A\&M University- San Antonio. For more information, please contact deirdre.mcdonald@tamusa.edu. 


\title{
The Invisible Scholar:
} Authors of Legal Scholarship in Criminology and Criminal Justice Journals

\author{
Brenda I. Rowe \\ Department of Social Sciences \\ Texas A \& M University - San Antonio \\ One University Way \\ San Antonio, TX 78224 \\ Email: Brenda.Rowe@tamusa.edu \\ Wesley S. McCann \\ Department of Criminal Justice and Criminology \\ Washington State University \\ 701 Johnson Tower \\ PO Box 644872 \\ Pullman, WA 99164-4872 \\ wmccann@wsu.edu \\ Phone: (509) 335-4031 \\ Craig Hemmens \\ Department of Criminal Justice and Criminology \\ Washington State University \\ 701 Johnson Tower \\ PO Box 644872 \\ Pullman, WA 99164-4872 \\ craig.hemmens@wsu.edu \\ Phone: (509) 335-4031
}

\begin{abstract}
About the Authors
Brenda I. Rowe, JD, PhD, is an assistant professor of Criminology and Criminal Justice at Texas A \& M University - San Antonio. Her research interests include legal issues in criminal justice, criminal justice legislation, and police-prosecutor relationships.

Wesley S. McCann, PhD, is a recent graduate of the Department of Criminal Justice and Criminology at Washington State University. He is currently a Visiting Assistant Professor at John Jay College of Criminal Justice. His research interests include legal issues in criminal justice, criminal justice policy, criminal law and procedure, terrorism, and counter-terrorism policy.

Craig Hemmens is chair and professor in the Department of Criminal Justice and Criminology at Washington State University. He has published more than 20 books and 200 articles and other writings on legal issues in criminal justice.
\end{abstract}




\title{
The Invisible Scholar:
} Authors of Legal Scholarship in Criminology and Criminal Justice Journals

\begin{abstract}
This study assesses the authorship of legal scholarship within 20 criminology and criminal justice (CCJ) journals from 2005 through 2015, examining trends over time and variation across journals in the prevalence of sole-authorship and the mean number of authors and identifying the most prolific authors of legal scholarship published in CCJ journals. The study thus sheds light on the extent of collaboration among CCJ legal scholars and identifies CCJ legal scholars who have remained largely invisible due to their focus on a marginalized subfield.
\end{abstract}

Key words: law, criminal justice, citations, peer review, scholarly publishing 


\section{The Invisible Scholar:} Authors of Legal Scholarship in Criminology and Criminal Justice Journals

Despite the importance of law in delineating what conduct constitutes crime (Hemmens, 2015a, 2016; Nolasco, del Carmen, Steinmetz, Vaughn, \& Spaic, 2015) and in setting limits on the criminal justice system's response to crime (Hemmens, 2015a, 2015b), law has been marginalized within the criminology and criminal justice (CCJ) discipline both with regard to the place of law-related courses in CCJ education (Hemmens, 2015a, 2015b, 2016; Nolasco et al., 2015) and the representation of legal scholarship in CCJ journals (Hemmens, 2016; Rowe, McCann, \& Hemmens, 2016). Recently, a growing number of CCJ scholars have made a persuasive argument that it is time to remedy the marginalization of legal scholarship within the CCJ discipline (Hemmens, 2015a, 2015b, 2016; Nolasco et al., 2015; Nolasco, Vaughn, \& del Carmen, 2010; Rowe et al., 2016). In light of this important discussion regarding the place of legal scholarship within the CCJ discipline, now is an opportune time to garner empirical evidence concerning the authorship of legal scholarship within the CCJ discipline, shedding light on the extent of collaboration among CCJ legal scholars and identifying CCJ legal scholars who have remained largely invisible to date due to their focus on a subfield which has been marginalized within the CCJ discipline. The present study seeks to do so using a sample which is suitable to specifically studying the authorship of legal scholarship published in CCJ journals.

This study will examine the percentage of legal articles which are sole-authored and the mean number of authors per legal article and compare these figures to the percentage of courts and sentencing articles which are sole-authored and the mean number of authors per courts and sentencing article. It will also examine trends over time and variations across journals in the percentage of articles which are sole-authored and the mean number of authors per article for 
both legal articles and courts and sentencing articles. Finally, this study will identify the most prolific authors of legal articles and the most prolific authors of courts and sentencing articles and compare the number of articles published by the authors in these two groups. The comparison between authorship of legal articles and authorship of courts and sentencing articles provides a useful point of comparison because courts and sentencing is a related, but distinct, area of CCJ scholarship which is better represented in CCJ journals than legal scholarship is, yet is still underrepresented, considering that courts are one of the three main components of the criminal justice system (Rowe et al., 2016). Also, identifying the most prolific authors of courts and sentencing articles is responsive to Rice, Terry, Miller, and Ackerman's (2007) call for research identifying the most productive scholars within the subdisciplines.

\section{Literature Review}

\section{Collaboration in CCJ Scholarship}

While there are no known studies specifically focusing on the authorship of legal scholarship published in CCJ journals, there is a body of literature examining articles published in CCJ journals which has findings pertaining to the authorship of CCJ journal articles more generally. Such research has found that multiple authorship is common (Crow \& Smykla, 2015; Fisher, Vander Ven, Cobane, Cullen, \& Williams, 1998; Gonzalez-Alcaide, Melero-Fuentes, Aleixandre-Benavent, \& Valderrama-Zurian, 2013; Sever, 2005; Tewksbury, Dabney, \& Copes, 2010; Tewksbury, DeMichele, \& Miller, 2005; Tewksbury \& Mustaine, 2011; Woodward, Webb, Griffin, \& Copes, 2016). While sole-authorship was once the norm, it is now relatively rare (Tewksbury \& Mustaine, 2011). Over time working alone has become less common for CCJ scholars and authorship teams have grown in size (Tewksbury \& Mustaine, 2011). 
Studies have found that there is variation in the percentage of CCJ journal articles which are sole-authored and the mean number of authors per article across journals (Crow \& Smykla, 2015; Sever, 2005; Tewksbury et al., 2010; Tewksbury et al., 2005; Tewksbury \& Mustaine, 2011; Woodward et al., 2016) and methodological approaches (Crow \& Smykla, 2015; Fisher et al., 1998; Tewksbury et al., 2005). Of particular relevance to the focus of the present study, Journal of Criminal Law and Criminology (JCLC), which has a section specifically devoted to legal scholarship, has a very high percentage of sole-authored articles (75.76\% during 19992000; Sever, 2005). Furthermore, CCJ journal articles employing legal analysis as the primary methodological orientation are more often sole-authored and have a lower mean number of authors per article compared to CCJ journal articles employing other methodologies (Tewksbury et al., 2005).

While there is research with findings pertaining to authorship of scholarship published in CCJ journals, prior studies have tended to rely on samples which excluded journals (such as JCLC; see e.g., Crow \& Smykla, 2015; Tewksbury et al., 2005; Woodward et al., 2016) and portions of journals (such as the criminal law section of JCLC; see e.g., Tewksbury et al., 2010; Tewksbury \& Mustaine, 2011) likely to include legal scholarship or employed article inclusion criteria which excluded important forms of legal scholarship (such as doctrinal legal research or “court case reviews;” see e.g., Steiner \& Schwartz, 2006, p. 395). Such samples are obviously not ideal for yielding empirical evidence which speaks directly to authorship of legal scholarship published in CCJ journals. There are preliminary indications, albeit based on problematic samples, that legal scholarship in CCJ differs in important respects, including prevalence of soleauthorship, from other CCJ scholarship (Sever, 2005; Tewksbury et al., 2005). Thus, there is reason to believe that prior studies of authorship of scholarship published in CCJ journals may 
not shed much light on the authorship of legal scholarship published in CCJ journals.

Consequently, there is a need for further research explicitly focused on the authorship of legal scholarship in CCJ journals that employs a sample which includes a broader range of journals, including journals which are more likely to feature legal scholarship, such as JCLC.

\section{Identification of the Most Productive Scholars in CCJ}

While there are no known studies specifically identifying which CCJ scholars are contributing the most to the relatively small body of legal scholarship published in CCJ journals, there is no shortage of research identifying the biggest contributors to CCJ scholarship more generally. There is a body of research ranking individual CCJ scholars in terms of scholarly productivity (see e.g., Cohn \& Farrington, 2014; Jennings, Schreck, Sturtz, \& Mahoney, 2008; Orrick \& Weir, 2011; Rice, Cohn, \& Farrington, 2005; Rice et al., 2007; Shutt \& Barnes, 2008; Weir \& Orrick, 2013) or influence (see e.g., Cohn \& Farrington, 2007, 2012; Cohn, Farrington, \& Iratzoqui, 2017; Wright, Malia, \& Johnson, 1999) or both (see e.g., Copes, Khey, \& Tewksbury, 2012; Khey, Jennings, Higgins, Schoepfer, \& Langton, 2011; Long, Boggess, \& Jennings, 2011), as well as a similar line of research ranking institutions (see e.g., Kleck \& Barnes, 2011; Kleck, Wang, \& Tark, 2007; Steiner \& Schwartz, 2006). Such studies often focus on top-ranked CCJ journals (see e.g., Cohn \& Farrington, 2007; Cohn et al., 2017; Jennings et al., 2008; Orrick \& Weir, 2011; Steiner \& Schwartz, 2006; Weir \& Orrick, 2013) or only journals indexed in certain databases (see e.g., Cohn \& Farrington, 2014; Copes et al., 2012; Kleck \& Barnes, 2011; Kleck et al., 2007). Some studies focus on a narrow group of CCJ scholars, such as faculty employed by doctoral granting programs (see e.g., Copes et al., 2012;

Kleck \& Barnes, 2011; Kleck et al., 2007), recent executive board members of professional 
organizations (Jennings et al., 2008), or certain cohorts of publishing stars (see e.g., Khey et al., 2011; Long et al., 2011; Rice et al., 2005, 2007; Shutt \& Barnes, 2008).

However, these ranking studies are unlikely to highlight those CCJ scholars who are the greatest producers of legal scholarship published in CCJ journals for several reasons. First, they often use samples which are not ideal for studying who is contributing the most to the relatively small body of legal scholarship published in CCJ journals due to: (1) the tendency to focus on top-ranked CCJ journals (see e.g., Cohn \& Farrington, 2007; Cohn et al., 2017; Jennings et al., 2008; Orrick \& Weir, 2011; Steiner \& Schwartz, 2006; Weir \& Orrick, 2013), the vast majority of which feature little legal scholarship (Rowe et al., 2016); (2) exclusion of JCLC (see e.g., Cohn \& Farrington, 2007, 2012), which publishes far more legal scholarship than other CCJ journals (Rowe et al., 2016) or the portion of JCLC which features legal scholarship; and (3) the use of article inclusion criteria which exclude doctrinal legal scholarship (see e.g., Steiner \& Schwartz, 2006).

Second, due to the marginalization of legal scholarship within the CCJ discipline, CCJ scholars who focus primarily on legal scholarship are unlikely to appear in general rankings of top CCJ scholars. Because legal scholarship constitutes a very small percentage of articles published in CCJ journals (Rowe et al., 2016), legal scholars are not likely to appear in lists of the most prolific publishers based on counts of articles published in CCJ journals. Likewise, legal scholars' work is unlikely to be cited in CCJ journals when legal scholarship rarely appears in CCJ journals, given that CCJ scholars tend to read and cite articles published in CCJ journals and that articles on non-legal topics would have relatively little need to cite legal articles. Therefore, one would not expect legal scholars to appear in lists of those who are most cited in CCJ articles either. 
Thus, the marginalization of legal scholarship in CCJ journals makes CCJ legal scholars largely invisible, ${ }^{1}$ as they tend not to appear in lists of either most productive or most influential CCJ scholars due to the scarce appearance of legal scholarship in CCJ journals, which naturally results in CCJ legal scholars' works being excluded from recognition or citation. A similar problem has been noted with regard to white collar crime scholars not showing up in studies identifying the most cited CCJ scholars due to their specialization in a marginalized subdiscipline (Shichor, 2009). Cohn and Farrington (2012) acknowledged that ranking studies may overlook scholars whose focus is a specialized subdiscipline due to sampling issues, such as restricting the sample to mainstream journals where scholarship in the specialized subdiscipline may not be well represented. In line with Rice et al.'s (2007) call for research on who the most productive scholars are within the subdisciplines (such as policing, courts, corrections, etc.), the present study will identify who is contributing the most to the small body of legal scholarship published in CCJ journals.

While studies ranking the most productive scholars in CCJ generally certainly serve other purposes, they cannot tell us who is contributing the most to the relatively small body of legal scholarship published in CCJ journals. Given the growing calls to remedy the marginalization of legal scholarship within the discipline (Hemmens, 2015a, 2015b, 2016; Nolasco et al., 2015, 2010), it is important to recognize the work of a group of scholars who are contributing to the body of knowledge for this marginalized yet important subdiscipline. Moreover, by recognizing those scholars who are publishing the most legal scholarship in CCJ journals, we are highlighting a group of scholars who may be able to help with efforts to remedy this marginalization by participating in interviews or focus groups aimed at generating knowledge regarding barriers to publishing legal scholarship in CCJ journals and successful strategies for publishing legal 
scholarship. This group of scholars might also be recruited to become part of an organized effort to remedy the marginalization of legal scholarship (through participation in mentorship networks, workshops designed to foster collaboration, supporting the founding of new CCJ journals which are receptive to legal scholarship, etc.). The present study therefore seeks specifically to identify who is contributing the most to the relatively small body of legal scholarship published in CCJ journals.

\section{Methods}

Building on earlier work by Rowe et al. (2016), which examined the representation of legal articles and courts and sentencing articles in CCJ journals, the present study uses a sample consisting of articles identified by Rowe et al. (2016) as legal articles and courts and sentencing articles from that study's larger sample of articles published from January 2005 through December 2015 in 20 CCJ journals: Criminology (CRIM); Justice Quarterly (JQ); Journal of Research in Crime and Delinquency (JRCD); Law and Society Review (LSR); JCLC; Crime and Delinquency (CD); Criminology and Public Policy (CPP); Journal of Quantitative Criminology (JQC); Theoretical Criminology (TC); Criminal Justice and Behavior (CJB); Journal of Criminal Justice (JCJ); Journal of Interpersonal Violence (JIV); Prison Journal (PJ); Police Quarterly (PQ); American Journal of Criminal Justice (AJCJ); Journal of Crime and Justice (JC\&J); Criminology, Criminal Justice, Law \& Society (CCJLS) $;{ }^{2}$ Punishment \& Society (PS); International Journal of Offender Therapy and Comparative Criminology (IJOTCC); and Youth Violence and Juvenile Justice (YVJJ). Rowe et al. (2016) selected these journals based on: (1) the first 13 journals listed being ranked in the top 10 by Sorensen, Snell, and Rodriguez's (2006) prestige ranking study, in which CCJ journals were ranked based on perceived prestige by members of the American Society of Criminology (ASC) and the Academy of Criminal Justice 
Sciences (ACJS), and Sorensen's (2009) impact ranking study, in which CCJ journals were ranked based on citation analysis; and (2) the following 7 journals being either affiliated with ASC or ACJS or being prominent journals focusing on important criminal justice topics, such as corrections and juvenile justice. This allowed for inclusion of well-known regional journals $(A J C J, J C \& J$, and $C C J L S)$ and also helped to balance out the representation of journals with respect to topical foci, which was important to ensuring that journals which may be likely to feature scholarship on legal topics were not excluded from the sample (Rowe et al., 2016), particularly in light of the dominance of criminology over criminal justice in top-ranked journals within the CCJ discipline (Steinmetz, Schaefer, del Carmen, \& Hemmens, 2014). Rowe et al. (2016) used article inclusion criteria which included "articles reporting original research (widely conceived, thus including articles which analyze, through doctrinal legal research methods, qualitative, or quantitative methods, any form of data, including legal authorities such as cases and statutes), research notes, and literature reviews" while excluding "book reviews, editorial introductions, letters, miscellany, corrections, obituaries, acknowledgements, and announcements" (p. 9). Thus, in addition to including CCJ journals known to be forums specifically devoted to publishing legal scholarship such as JCLC and $L S R$, the article inclusion criteria were broad enough to include the various forms of legal scholarship, including doctrinal legal research.

The sample for the present study consists of articles identified by Rowe et al. (2016) as legal articles and courts and sentencing articles from that study's larger sample. Rowe et al. (2016) classified legal articles as follows:

Articles were classified as legal articles if the primary focus of the article was: (1) the law, litigation, or legal decisions pertaining to criminal procedure, criminal law, or legal 
issues impacting the criminal justice system in general; or (2) how criminal law, criminal procedure, or criminal justice policy and legislation were related to society at large or other facets of the criminal justice system in part or in whole (police, courts, corrections, etc.). Either of these criteria can be satisfied when articles rely on or examine legal doctrine, legal theory, statutes, case law, or evaluations of laws and legislation. . . . articles which had a topical or tangential focus on law or the relationship between law and society, but which were not primarily or solely focused on criminal procedure, criminal law, or legal issues affecting criminal justice were not counted as legal articles. In short, articles which focused on law but were not criminal justice-oriented were not coded. . . . Note that this definition of legal scholarship is based on topical focus and is not restricted to any particular methodology (pp. 8-9).

In delineating courts and sentencing articles from legal articles, Rowe et al. (2016) classified the former as articles with a primary focus on courts and sentencing topics. This operationalization contends that:

Articles were classified as courts and sentencing articles if the primary focus of the article was criminal courts or sentencing. This includes courtroom actors (judicial discretion, juror decision-making, prosecutorial discretion, or defense counsel and indigent defense), sentencing, the courtroom work group, or other aspects of courts and sentencing, which are not primarily or solely focused on the law. Many courts and sentencing articles contained some legal component due to their focus. However, distinguishing between legal and courts and sentencing articles is necessary and is achieved not just through the examination of the length of focus on either category, but is also dependent on what the main focus or purpose each article serves as a whole. . . 
Similar to legal articles, many articles were also excluded from being counted to courts and sentencing articles if they had no relation to criminal justice or criminology (pp. 8-9). Interested readers can consult the Rowe et al. (2016) study for full details regarding the methodology of that study, including illustrative examples of the classification of articles as legal articles or courts and sentencing articles.

The present study uses data from the Rowe et al. (2016) study for the variables of article type (legal versus courts and sentencing article), journal title, and publication year, plus additional data for the variables of sole-authorship status of the article, number of authors, and author names by author position. The data was coded in accordance with a codebook, which was first pilot tested by multiple authors independently coding all articles published in one journal over a three-year span and discussing differences in coding to reach a common understanding, which then informed revisions to coding instructions to guide future coding decisions (Rowe et al., 2016). The data for the present study were analyzed through the use of descriptive statistics, line graphs, and bar charts.

\section{Findings}

First, we assessed the extent to which CCJ legal scholars collaborate by examining the percentage of legal articles which are sole-authored and the mean number of authors per legal article and comparing these figures to the percentage of courts and sentencing articles which are sole-authored and the mean number of authors per courts and sentencing article. As shown in Table 1, more than two-thirds (67.91\%) of legal articles are sole-authored. In contrast, a little more than one-third (34.52\%) of courts and sentencing articles are sole-authored. Thus, the percentage of sole-authored articles is nearly double for legal articles compared to courts and sentencing articles. Concomitantly, the mean number of authors per legal article is 1.50 , which is 
substantially lower than the mean number of authors per courts and sentencing article of 2.19 . In sum, authors of legal scholarship who published in CCJ journals largely work alone on their scholarship and their authorship teams are smaller on average compared to the authorship teams of courts and sentencing scholarship.

\section{-----Insert Table 1 About Here-----}

Next, we assessed trends in collaboration by examining the percentage of articles which are sole-authored over time for legal articles and for courts and sentencing articles and the mean number of authors per article over time for legal articles and for courts and sentencing articles. As shown in Figure 1, the percentage of legal articles which are sole-authored has clearly declined over time, with a dramatic decline in the last two years (declining from $70 \%$ to $50 \%$ during 2013 to 2015; see also Table 1). The trend in the percentage of courts and sentencing articles which are sole-authored has been somewhat more erratic over the years and exhibited a sudden drop between 2013 and 2014 (falling from about $46 \%$ in 2013 to about $26 \%$ in 2014 and then remaining level for 2015; see also Table 1). Overall, the trend lines indicate that the percentage of articles which are sole-authored has declined over the 11-year period (2005 through 2015) for both legal articles and courts and sentencing articles, and both types of articles exhibit a sharp decline in the percentage of articles which are sole-authored in recent years.

\section{-----Insert Figure 1 About Here----- \\ -----Insert Figure 2 About Here-----}

Figure 2 depicts a comparison of the trend lines for the mean number of authors per legal article over time and the mean number of authors per courts and sentencing article over time. Over the 11-year period, the mean number of authors has increased for both legal articles and courts and sentencing articles, rising from 1.36 to 2.00 for legal articles and from 2.05 to 2.44 for 
courts and sentencing articles (see also Table 1). The mean number of authors for legal articles exhibited a steep increase from 2013 to 2015 (from 1.47 to 2.00). The mean number of authors for courts and sentencing articles rose sharply between 2013 and 2014 (from 2.03 to 2.71) and then declined the following year (to 2.44). In sum, while authors of legal scholarship published in CCJ journals are much more likely to work alone and have smaller authorship teams on average compared to authors of courts and sentencing scholarship, the trend for authors of both types of articles over the 11-year period (2005 through 2015) has been towards increasing collaboration, with the percentage of articles which are sole-authored declining over time and the mean number of authors increasing over time, and this increase in collaboration has accelerated in recent years.

Next, we assessed variation by journal in percentage of articles which are sole-authored by article type and mean number of authors per article by article type. As shown in Table 2, there is wide variation across journals in the percentage of articles which are sole-authored for both legal articles (ranging from $0 \%$ in $C R I M, J R C D, C D, J C J$, and $Y V J J$ to $100 \%$ in $C C J L S$ ) and courts and sentencing articles (ranging from $7.41 \%$ in $A J C J$ to $75 \%$ in $C C J L S$ ) and in the mean number of authors per article for both legal articles (ranging from 1.00 in $C C J L S$ to 3.00 in $C D$ ) and courts and sentencing articles (ranging from 1.25 in $T C$ and $C C J L S$ to 2.96 in $C J B$ ).

-----Insert Table 2 About Here-----

Comparing these indicators of collaboration within each journal across article types yields some interesting findings as well. When looking at the four journals which published the most legal articles, three of those journals $(L S R, J C L C$, and $A J C J)$ have a substantially higher percentage of articles which are sole-authored for legal articles compared to courts and sentencing articles, with difference ranging from about $9 \%$ to $29 \%$. In the fourth journal, $P S$, the 
percentage of legal articles which are sole-authored (60.00\%) is roughly similar to the percentage of courts and sentencing articles which are sole-authored (61.90\%). Note also that one journal stands out as having a remarkable disparity in the percentage of articles which are sole-authored by article type. In $P J$, which published roughly the same number of legal articles and courts and sentencing articles, the percentage of legal articles which are sole-authored $(57.14 \%)$ is a little over 4.5 times more than the percentage of courts and sentencing articles which are soleauthored $(12.50 \%)$.

Figure 3 visually depicts the comparison of percentage of articles which are sole-authored by article type across journals. Of the 18 journals which published both legal articles and courts and sentencing articles, in 10 of those journals the percentage of legal articles which are soleauthored is higher than the percentage of courts and sentencing articles which are sole-authored, and those differences range from $4 \%$ to $45 \%$ (see also Table 2 ). The other 8 journals have a higher percentage of courts and sentencing articles which are sole-authored than the percentage of legal articles which are sole-authored, and those differences range from $2 \%$ to $29 \%$ (see also Table 2). Based on the data presented in Table 2, note that in 7 of these 8 journals, very few legal articles were published and the number of courts and sentencing articles published greatly exceeded the number of legal articles published. In contrast, of the 10 journals which had a higher percentage of legal articles which are sole-authored than the percentage of courts and sentencing articles which are sole-authored, only 2 of those journals (JCLC and TC) published more legal articles than courts and sentencing articles and only one of those journals published far more legal articles than courts and sentencing articles (JCLC, which published 158 legal articles and 56 courts and sentencing articles). Thus, it appears that generally, a higher percentage of legal articles are sole-authored compared to courts and sentencing articles in most 
journals, and the journals which have a higher percentage of courts and sentencing articles which are sole-authored tend to be journals in which very few legal articles are published, and the number of courts and sentencing articles published greatly exceeds the number of legal articles published.

\section{-----Insert Figure 3 About Here-----}

Figure 4 illustrates the comparison of mean number of authors per article by article type across journals. Of the 18 journals which published both legal articles and courts and sentencing articles, in 15 of those journals the mean number of authors per article is lower for legal articles than for courts and sentencing articles, and those differences range from .01 to .81 (see also Table 2). For the other 3 journals $(J Q, C D$, and $\mathrm{JC} \& \mathrm{~J})$ in which the mean number of authors per article is higher for legal articles than for courts and sentencing articles (with the difference ranging from .11 to .98), note that, based on the data presented in Table 2, all of these journals publish very few legal articles and publish far more courts and sentencing articles than legal articles. In sum, the mean number of authors per article is lower for legal articles than for courts and sentencing articles in the vast majority of journals (15 out of 18) which published both legal articles and courts and sentencing articles, and the small minority of journals in which the mean number of authors per article is higher for legal articles than for courts and sentencing articles are journals which publish very few legal articles and publish far more courts and sentencing articles than legal articles.

\section{-----Insert Figure 4 About Here-----}

Finally, we identified the most prolific authors of legal articles by authorship position and the most prolific authors of courts and sentencing articles by authorship position. As shown in Table 3, relatively few unique authors authored more than one legal article in any of the 
authorship positions (lead/sole author, subsequent author, and both authorship positions combined) and no unique authors authored more than three legal articles in any of the authorship positions. In contrast, a substantial number of unique authors authored two courts and sentencing articles in each of the authorship positions and there was no shortage of unique authors authoring more than three courts and sentencing articles in each of the authorship positions. Due to it being relatively rare for unique authors of legal articles to author more than one legal article in any authorship position, the threshold for identifying an author as one of the most prolific authors of legal articles by authorship position was set at authoring more than one legal article in that authorship position. While authoring more than one article may seem like a relatively low threshold, it is appropriate to identify these scholars as the most prolific authors of legal articles since this is a relative comparison to other authors who published legal articles and given the extreme underrepresentation of legal scholarship in CCJ journals (Rowe et al., 2016). Due to there being a substantial number of unique authors who authored two courts and sentencing articles in each of the authorship positions and far fewer who authored three or more courts and sentencing articles in each of the authorship positions, the threshold for identifying an author as one of the most prolific authors of courts and sentencing articles by authorship position was set at authoring more than two courts and sentencing articles in that authorship position.

\section{-----Insert Table 3 About Here-----}

Table 4 presents the most prolific authors of legal articles by authorship position. This table includes authors who, for a given authorship position (lead/sole author, subsequent author, or any position), authored more than one legal article in the sample. Note that even among the most prolific authors of legal articles, these authors published relatively few legal articles. The highest number of legal articles published by any author in any of the authorship positions was 
three articles, and very few authors of legal articles published three legal articles in any of the authorship positions. Only one author, Kit Kinports, published three legal articles in the lead/sole authorship position. Two authors, Bruce A. Arrigo and Michael S. Vaughn, published three legal articles in the subsequent authorship position. Three authors published three legal articles in total, regardless of authorship position (when legal articles published as lead/sole author and legal articles published as subsequent author are combined): Bruce A. Arrigo, Kit Kinports, and Michael S. Vaughn. ${ }^{3}$ The remainder of the authors identified as among the most prolific authors of legal articles published only two legal articles for any given authorship position.

\section{-----Insert Table 4 About Here-----}

Table 5 presents the most prolific authors of courts and sentencing articles by authorship position. This table includes authors who, for a given authorship position, authored more than two courts and sentencing articles in the sample. Note that, in contrast to authors of legal articles publishing relatively few legal articles (with three legal articles being the most legal articles any unique author published), the most prolific authors of courts and sentencing articles published a fairly high number of courts and sentencing articles. The highest number of courts and sentencing articles published by any author was 14 . Furthermore, 24 authors published more than three courts and sentencing articles. Publishing more than four courts and sentencing articles was relatively rarer, however. Seven authors published more than four courts and sentencing articles in the lead/sole authorship position: Brian D. Johnson, John Wooldredge, Michael J. Leiber, Jeffrey T. Ulmer, Shawn D. Bushway, Richard D. Hartley, and Travis W. Franklin. Only three authors published more than four courts and sentencing articles in the subsequent authorship position: Cassia Spohn, William Bales, and Marc Getz. Thirteen authors published more than four courts and sentencing articles in total, regardless of authorship position (when courts and 
sentencing articles published as lead/sole author and courts and sentencing articles published as subsequent author are combined): Cassia Spohn, Brian D. Johnson, John Wooldredge, Michael J. Leiber, William Bales, Jeffrey T. Ulmer, Richard D. Hartley, Daniel P. Mears, Shawn D. Bushway, Nancy Rodriguez, Marc Getz, Tina L. Freiburger, and Travis W. Franklin.

-----Insert Table 5 About Here-----

\section{Discussion and Conclusion}

Authors of legal scholarship published in CCJ journals often work alone on their research. More than two-thirds (67.91\%) of legal articles published in CCJ journals are soleauthored and the mean number of authors per legal article is 1.50 . This stands in stark contrast to the just over one-third (34.52\%) of courts and sentencing articles which are sole-authored and the mean number of authors per courts and sentencing article of 2.19. Thus, legal scholars in CCJ are far more likely to work alone and have smaller authorship teams on average compared to courts and sentencing scholars. These findings are generally in line with prior research which indicates that JCLC, a journal which has a section dedicated to featuring legal scholarship, has a high percentage (75.76\%) of sole-authored articles compared to other journals (Sever, 2005) and CCJ journal articles using a legal analysis methodological approach are more often sole-authored (57.1\% versus $24.7 \%$ of articles sole-authored) and have smaller authorship teams on average (1.71 versus 2.6 mean number of authors per article) compared to quantitative articles (Tewksbury et al., 2005).

The trend for both legal scholars in CCJ and courts and sentencing scholars is towards increasing collaboration. From 2005 through 2015, the percentage of sole-authored articles declined from $76 \%$ to $50 \%$ for legal articles and from about $42 \%$ to about $27 \%$ for courts and sentencing articles while the mean number of authors per article increased from 1.36 to 2.00 for 
legal articles and from 2.05 to 2.44 for courts and sentencing articles. These findings are consonant with prior research which indicates a downward trend in the percentage of CCJ journal articles which are sole-authored and an upward trend in the size of authorship teams (Tewksbury \& Mustaine, 2011).

For both legal articles and courts and sentencing articles, there is wide variation across journals in the percentage of articles which are sole-authored and the mean number of authors per article. This is consistent with prior research which found variation across journals in these measures of collaboration (Sever, 2005; Tewksbury et al., 2010, 2005; Tewksbury \& Mustaine, 2011; Woodward et al., 2016). When making comparisons within each journal across article types, in the majority of journals, legal articles are less collaborative (higher percentage soleauthored and lower mean number of authors per article) than courts and sentencing articles.

The most prolific authors of legal scholarship authored relatively few legal articles. In fact, three legal articles was the highest number of legal articles any unique author published. This is likely due to the underrepresentation of legal scholarship in CCJ journals (Rowe et al., 2016). With so few legal articles appearing in CCJ journals (Rowe et al., 2016), even the most prolific legal scholars in CCJ publish relatively few legal articles in CCJ journals. In contrast, the most prolific authors of courts and sentencing articles published a fairly high amount of courts and sentencing articles, with 14 being the most courts and sentencing articles any unique author published.

The present study has identified the most prolific authors of legal scholarship in the sample of CCJ journal articles. This list may prove useful in delineating a population to be interviewed in future studies in order to elicit information on how to structure a legal manuscript which is more likely to be well received by CCJ journal editors and peer reviewers and how to 
successfully navigate the process of submitting and revising a legal manuscript for publication in a CCJ journal. Such interviews might also collect data on CCJ legal scholars' experiences during the process of submitting legal manuscripts to $\mathrm{CCJ}$ journals and receiving peer reviews (in line with Rowe et al.'s, 2016, suggestions for future research). Such research can contribute to the growing body of literature on legal scholarship within the CCJ discipline and may provide guidance to new CCJ legal scholars regarding the publication process.

The list of the most prolific authors of legal scholarship may also serve as a starting point for identifying CCJ scholars who may be able to contribute to efforts to remedy the marginalization of legal scholarship within the CCJ discipline. Such efforts might include conference workshops designed to provide junior CCJ legal scholars with feedback on their works in progress and guidance on the publishing process, conference panels on how to publish legal research in CCJ journals, and grass roots organizing to support the formation of CCJ journals devoted to publishing legal research (addressing recent calls to remedy the shortage of peer-reviewed outlets within the CCJ discipline for scholarship on legal issues in criminal justice; Hemmens, 2015b, 2016; Rowe et al., 2016). ${ }^{4}$ Given that the present study indicates that CCJ legal scholars often work alone on their research, efforts to remedy the marginalization of legal scholarship within the CCJ discipline might also focus on the formation of mentorship networks for new CCJ legal scholars. Increased mentorship may contribute to more CCJ legal scholars successfully publishing legal scholarship in CCJ journals by providing less experienced scholars with valuable guidance regarding the process of conducting legal research, submitting legal research to CCJ journals, and effectively addressing peer reviewers' concerns regarding legal research methodology (which may reflect lack of familiarity with standards for legal research; Nolasco et al., 2010). ${ }^{5}$ 
Remedying the marginalization of legal scholarship within the CCJ discipline can have a positive impact on both CCJ education and the advancement of knowledge in the CCJ discipline (Hemmens, 2015b). Given the importance of publishing articles in peer-reviewed journals for promotion and tenure decisions (Gabbidon, Higgins, \& Martin, 2011) as well as merit raises, the current scarcity of legal scholarship in CCJ journals provides a disincentive to CCJ scholars pursuing a research agenda that focuses on legal issues within the field of criminal justice, since CCJ scholars may logically conclude that the path of least resistance to earning promotion and tenure and merit raises is to conduct research on topics which are much more commonly published in CCJ journals (Rowe et al., 2016). ${ }^{6}$ Unfortunately, this may deprive students of the opportunity to be taught by CCJ scholars whose teaching is informed by their research on current developments in legal issues impacting criminal justice (Rowe et al., 2016). Successful efforts to remedy the marginalization of legal scholarship within the CCJ discipline have the potential to remove this disincentive to conducting research on important legal issues in criminal justice, which may contribute to more CCJ scholars actively conducting such research. This would benefit students who consequently may receive instruction provided by teacher-scholars whose teaching is informed by their research on the most recent legal developments impacting criminal justice (Hemmens, 2015b).

Remedying the marginalization of legal scholarship within the CCJ discipline would also positively impact the advancement of knowledge in the discipline (Hemmens, 2015a, 2016). Increasing legal scholarship in CCJ journals can provide CCJ faculty, who typically rely on reading CCJ journals as their means of keeping abreast of developments in disciplinary knowledge, with the benefit of research which sheds light on legal issues impacting criminal justice administration (Rowe et al., 2016). If CCJ scholars conduct more legal research, they can 
also produce knowledge which may inform criminal justice practitioners' policy decisions (Hemmens, 2015a, 2015b, 2016).

The present study contributes to the relatively scant empirical knowledge base regarding legal scholarship published in CCJ journals by examining collaboration on legal scholarship published in CCJ journals and identifying the most prolific authors of legal scholarship published in CCJ journals. Directions for future research include survey research examining legal scholars' reasons for not collaborating and identifying any barriers to collaboration, research on authorship of legal scholarship published in international CCJ journals, and research on authorship of legal scholarship within the CCJ discipline in forums other than CCJ journals (such as books, textbooks, etc.). Studies identifying the most prolific scholars within the other subdisciplines within CCJ may also be warranted (as previously called for by Rice et al., 2007).

\section{Endnotes}

${ }^{1}$ While there are a select few legal scholars who are well known, often their prominence arises from textbook publications, stature within professional organizations, and publishing journal articles on a variety of CCJ topics in addition to publishing legal scholarship.

${ }^{2}$ CCJLS was formerly known as Western Criminology Review.

${ }^{3}$ Due to the focus of the present study being on authorship of legal scholarship within CCJ journals, the methodology does not capture CCJ legal scholars who publish primarily in law reviews, which is increasingly common due to the marginalization of legal scholarship within CCJ journals.

${ }^{4}$ The Academy of Criminal Justice Sciences' Law and Public Policy Section recently adopted as its official journal The Journal of Criminal Justice and Law: A Publication of the Law and 
Public Policy Section of the Academy of Criminal Justice Sciences. While this is certainly a positive development, given the vast underrepresentation of legal scholarship in CCJ journals (Rowe et al., 2016), the founding of additional journals receptive to legal scholarship, as well as efforts to encourage editors of existing journals to be more open to publishing legal scholarship, is still warranted.

${ }^{5}$ Authors of legal scholarship often face desk rejections and peer reviews indicating that legal scholarship does not fit within the scope of the journal and would be more appropriate for a law review (Hemmens, 2015b, 2016). This devaluation of legal scholarship may be in part due to the lack of required legal scholarship courses in CCJ Ph.D. programs (Hemmens, 2015a, 2016), which leads to misunderstandings about the nature of legal research among those programs' graduates (Nolasco et al., 2010).

${ }^{6} \mathrm{CCJ}$ legal scholars are increasingly relegated to publishing in law reviews due to the lack of receptiveness to legal scholarship exhibited by $\mathrm{CCJ}$ journal editors and peer reviewers (Hemmens, 2015b, 2016). This is problematic because law review publications, which are often not peer reviewed, may be treated as inferior during evaluations for promotion and tenure (Hemmens, 2015b, 2016). Ironically, some law reviews have higher impact factors than highly ranked CCJ journals do. Unfortunately, when CCJ legal scholars publish in law reviews due to editors' feedback indicating that legal scholarship belongs in law reviews (Hemmens, 2015b, 2016), CCJ legal scholars become marginalized within the CCJ discipline. 


\section{References}

Cohn, E. G., \& Farrington, D. P. (2007). Changes in scholarly influence in major American criminology and criminal justice journals between 1986 and 2000. Journal of Criminal Justice Education, 18(1), 6-34. doi: 10.1080/10511250601144225

Cohn, E. G., \& Farrington, D. P. (2012). Scholarly influence in criminology and criminal justice journals in 1990-2005. Criminal Justice Review, 37(3), 360-383. doi: $10.1177 / 0734016812450025$.

Cohn, E. G., \& Farrington, D. P. (2014). Publication productivity of criminologists. Journal of Criminal Justice Education, 25(3), 275-303. doi: 10.1080/10511253.2014.889728

Cohn, E. G., Farrington, D. P., \& Iratzoqui, A. (2017). Changes in the most-cited scholars and works over 25 years: The evolution of the field of criminology and criminal justice. Journal of Criminal Justice Education, 28(1), 25-51. doi: $10.1080 / 10511253.2016 .1153686$

Copes, H., Khey, D. N., \& Tewksbury, R. (2012). Criminology and criminal justice hit parade: Measuring academic productivity in the discipline. Journal of Criminal Justice Education, 23(4), 423-440. doi: 10.1080/10511253.2012.683016

Crow, M. S., \& Smykla, J. O. (2015). An examination of author characteristics in national and regional criminology and criminal justice journals, 2008-2010: Are female scholars changing the nature of publishing in criminology and criminal justice? American Journal of Criminal Justice, 40, 441-455. doi: 10.1007/s12103-014-9250-х

Fisher, B., Vander Ven, T., Cobane, C., Cullen, F., \& Williams, N. (1998). Trends in multiple authored articles in criminology and criminal justice: A comparative analysis. Journal of Criminal Justice Education, 9, 19-38. 
Gabbidon, S.L., Higgins, G.E., \& Martin, F. (2011). Moving through the faculty ranks: An exploratory study on the perceived importance of book publishing and publishing in peerreviewed journals in criminology/criminal justice. Journal of Criminal Justice Education, 22(2), 165-180. doi: 10.1080/10511253.2010.517767

Gonzalez-Alcaide, G., Melero-Fuentes, D., Aleixandre-Benavent, R., \& Valderrama-Zurian, J.C. (2013). Productivity and collaboration in scientific publications on criminology. Journal of Criminal Justice Education, 24(1), 15-37. doi:

$10.1080 / 10511253.2012 .664153$

Hemmens, C. (2015a). We (should) take care of our own: The role of law and lawyers in criminal justice and criminology programs. Justice Quarterly 32(5), 749-767.

Hemmens, C. (2015b, May). Why criminal procedure should matter to criminal justice departments. ACJS Today, 40(3), 21-25. Retrieved from http://www.acjs.org/pubs/167_666_3516.cfm

Hemmens, C. (2016). Teaching law and courts in criminal justice: Outside looking in. Journal of Criminal Justice Education 27(4), 497-508.

Jennings, W. G., Schreck, C. J., Sturtz, M., \& Mahoney, M. (2008). Exploring the scholarly output of academic organization leadership in criminology and criminal justice: A research note on publication productivity. Journal of Criminal Justice Education, 19(3), 404-416. doi: 10.1080/10511250802476228

Khey, D. N., Jennings, W. G., Higgins, G. E., Schoepfer, A., \& Langton, L. (2011). Re-ranking the top female academic "stars" in criminology and criminal justice using an alternative method: A research note. Journal of Criminal Justice Education, 22(1), 118-129. doi: $10.1080 / 10511253.2010 .517655$ 
Kleck, G., \& Barnes, J. C. (2011). Article productivity among the faculty of criminology and criminal justice doctoral programs, 2005-2009. Journal of Criminal Justice Education, 22(1), 43-66. doi: 10.1080/10511253.2010.517650

Kleck, G., Wang, S.-Y. K., \& Tark, J. (2007). Article productivity among the faculty of criminology and criminal justice doctoral programs, 2000-2005. Journal of Criminal Justice Education, 18(3), 385-405. doi: 10.1080/10511250701705347

Long, H., Boggess, L. N., \& Jennings, W. G. (2011). Re-assessing publication productivity among academic "stars" in criminology and criminal justice. Journal of Criminal Justice Education, 22(1), 102-117. doi: 10.1080/10511253.2010.517654

Nolasco, C. A. R. I., del Carmen, R. V., Steinmetz, K. F., Vaughn, M. S., \& Spaic, A. (2015). Building legal competency: Foundations for a more effective criminology and criminal justice discipline. Journal of Criminal Justice Education 26(3), 233-252.

Nolasco, C. A. R. I., Vaughn, M. S., \& del Carmen, R. V. (2010). Toward a new methodology for legal research in criminal justice. Journal of Criminal Justice Education, 21(1), 1-23.

Orrick, E. A., \& Weir, H. (2011). The most prolific sole and lead authors in elite criminology and criminal justice journals, 2000-2009. Journal of Criminal Justice Education, 22(1), 24-42. doi: 10.1080/10511253.2010.517649

Rice, S. K., Cohn, E. G., \& Farrington, D. P. (2005). Where are they now? Trajectories of publication "stars" from American criminology and criminal justice programs. Journal of Criminal Justice Education, 16(2), 244-264. doi: 10.1080/10511250500082203

Rice, S. K., Terry, K. J., Miller, H. V., \& Ackerman, A. R. (2007). Research trajectories of female scholars in criminology and criminal justice. Journal of Criminal Justice Education, 18(3), 360-384. doi: 10.1080/10511250701705305 
Rowe, B. I., McCann, W. S., \& Hemmens, C. (2016). Persona non grata: The marginalization of legal scholarship in criminology and criminal justice journals. Journal of Criminal Justice Education. Advance online publication. doi: 10.1080/10511253.2016.1267242

Sever, B. (2005). Ranking multiple authors in criminal justice scholarship: An examination of underlying issues. Journal of Criminal Justice Education, 16(1), 79-100. doi: $10.1080 / 1051125042000333479$

Shichor, D. (2009). "Scholarly influence" and white-collar crime scholarship. Crime, Law and Social Change, 51(1), 175-187. doi: 10.1007/s10611-008-9149-x

Shutt, J. E., \& Barnes, J. C. (2008). Reexamining criminal justice "star power" in a larger sky: A belated response to Rice et al. on sociological influence in criminology and criminal justice. Journal of Criminal Justice Education, 19(2), 213-226. doi:

$10.1080 / 10511250802137440$

Sorensen, J.R. (2009). An assessment of the relative impact of criminal justice and criminology journals. Journal of Criminal Justice, 37, 505-511. doi: 10.1016/j.jcrimjus.2009.07.012

Sorensen, J., Snell, C., \& Rodriguez, J.J. (2006). An assessment of criminal justice and criminology journal prestige. Journal of Criminal Justice Education, 17(2), 297-322. doi: $10.1080 / 10511250500336203$

Steiner, B., \& Schwartz, J. (2006). The scholarly productivity of institutions and their faculty in leading criminology and criminal justice journals. Journal of Criminal Justice, 34, 393400. doi: 10.1016/j.jcrimjus.2006.05.005

Steinmetz, K.F., Schaefer, B.P., del Carmen, R.V., \& Hemmens, C. (2014). Assessing the boundaries between criminal justice and criminology. Criminal Justice Review, 39(4), 357-376. doi: 10.1177/0734016814532100 
Tewksbury, R., Dabney, D. A., \& Copes, H. (2010). The prominence of qualitative research in criminology and criminal justice scholarship. Journal of Criminal Justice Education, 21(4), 391-411. doi: 10.1080/10511253.2010.516557

Tewksbury, R., DeMichele, M. T., \& Miller, J. M. (2005). Methodological orientations of articles appearing in criminal justice's top journals: Who publishes what and where. Journal of Criminal Justice Education, 16(2), 265-279. doi: $10.1080 / 10511250500082278$

Tewksbury, R., \& Mustaine, E. E. (2011). How many authors does it take to write an article? An assessment of criminology and criminal justice research article author composition. Journal of Criminal Justice Education, 22(1), 12-23. doi:

$10.1080 / 10511253.2010 .517648$

Weir, H., \& Orrick, E. (2013). The most prolific female scholars in elite criminology and criminal justice journals, 2000-2010. Journal of Criminal Justice Education, 24(3), 273289. doi: $10.1080 / 10511253.2012 .709258$

Woodward, V. H., Webb, M. E., Griffin, O. H., \& Copes, H. (2016). The current state of criminological research in the United States: An examination of research methodologies in criminology and criminal justice journals. Journal of Criminal Justice Education, 27(3), 340-361. doi: 10.1080/10511253.2015.1131312

Wright, R. A., Malia, M., \& Johnson, C. W. (1999). Invisible influence: A citation analysis of crime and justice articles published in leading sociology journals. Journal of Crime and Justice, 22(2), 147-169. doi: 10.1080/0735648X.1999.9721098 


\section{Tables}

Table 1

Comparison of Authorship Characteristics of Legal Articles and Courts \& Sentencing Articles by Year

\begin{tabular}{|c|c|c|c|c|c|c|c|c|}
\hline \multirow[b]{2}{*}{ Year } & \multicolumn{2}{|c|}{ Articles $^{a}$} & \multicolumn{2}{|c|}{ Sole-authored } & \multicolumn{2}{|c|}{$\%$ sole-authored } & \multicolumn{2}{|c|}{ No. of authors (M) } \\
\hline & Legal & $\begin{array}{c}\text { Courts \& } \\
\text { sentencing }\end{array}$ & Legal & $\begin{array}{c}\text { Courts \& } \\
\text { sentencing }\end{array}$ & Legal & $\begin{array}{c}\text { Courts \& } \\
\text { sentencing }\end{array}$ & Legal & $\begin{array}{l}\text { Courts \& } \\
\text { sentencing }\end{array}$ \\
\hline 2005 & 25 & 38 & 19 & 16 & 76.00 & 42.11 & 1.36 & 2.05 \\
\hline 2006 & 24 & 26 & 15 & 10 & 62.50 & 38.46 & 1.58 & 1.88 \\
\hline 2007 & 28 & 53 & 17 & 19 & 60.71 & 35.85 & 1.61 & 2.08 \\
\hline 2008 & 22 & 35 & 14 & 11 & 63.64 & 31.43 & 1.64 & 2.11 \\
\hline 2009 & 25 & 30 & 20 & 14 & 80.00 & 46.67 & 1.24 & 1.97 \\
\hline 2010 & 21 & 57 & 16 & 18 & 76.19 & 31.58 & 1.29 & 2.32 \\
\hline 2011 & 26 & 38 & 19 & 8 & 73.08 & 21.05 & 1.35 & 2.26 \\
\hline 2012 & 30 & 34 & 20 & 13 & 66.67 & 38.24 & 1.57 & 2.09 \\
\hline 2013 & 30 & 37 & 21 & 17 & 70.00 & 45.95 & 1.47 & 2.03 \\
\hline 2014 & 25 & 38 & 15 & 10 & 60.00 & 26.32 & 1.68 & 2.71 \\
\hline 2015 & 12 & 34 & 6 & 9 & 50.00 & 26.47 & 2.00 & 2.44 \\
\hline All & 268 & 420 & 182 & 145 & 67.91 & 34.52 & 1.50 & 2.19 \\
\hline
\end{tabular}


Table 2

Comparison of Authorship Characteristics of Legal Articles and Courts \& Sentencing Articles by Journal

\begin{tabular}{|c|c|c|c|c|c|c|c|c|}
\hline \multirow[b]{2}{*}{ Journal } & \multicolumn{2}{|c|}{ Articles $^{\mathrm{a}}$} & \multicolumn{2}{|c|}{ Sole-authored } & \multicolumn{2}{|c|}{$\%$ sole-authored } & \multicolumn{2}{|c|}{ No. of authors (M) } \\
\hline & Legal & $\begin{array}{c}\text { Courts \& } \\
\text { sentencing }\end{array}$ & Legal & $\begin{array}{c}\text { Courts \& } \\
\text { sentencing }\end{array}$ & Legal & $\begin{array}{c}\text { Courts \& } \\
\text { sentencing }\end{array}$ & Legal & $\begin{array}{c}\text { Courts \& } \\
\text { sentencing }\end{array}$ \\
\hline CRIM & 1 & 25 & 0 & 3 & 0.00 & 12.00 & 2.00 & 2.56 \\
\hline JRCD & 1 & 11 & 0 & 3 & 0.00 & 27.27 & 2.00 & 2.27 \\
\hline LSR & 16 & 28 & 10 & 15 & 62.50 & 53.57 & 1.63 & 1.86 \\
\hline JCLC & 158 & 56 & 135 & 40 & 85.44 & 71.43 & 1.20 & 1.50 \\
\hline $\mathrm{CD}$ & 2 & 42 & 0 & 9 & 0.00 & 21.43 & 3.00 & 2.50 \\
\hline CPP & 3 & 21 & 2 & 8 & 66.67 & 38.10 & 1.33 & 2.00 \\
\hline JQC & 0 & 16 & 0 & 5 & & 31.25 & & 2.00 \\
\hline TC & 6 & 4 & 5 & 3 & 83.33 & 75.00 & 1.17 & 1.25 \\
\hline CJB & 4 & 23 & 1 & 2 & 25.00 & 8.70 & 2.75 & 2.96 \\
\hline $\mathrm{JCJ}$ & 7 & 35 & 0 & 10 & 0.00 & 28.57 & 2.29 & 2.37 \\
\hline YVJJ & 1 & 16 & 0 & 2 & 0.00 & 12.50 & 2.00 & 2.56 \\
\hline JIV & 3 & 18 & 1 & 4 & 33.33 & 22.22 & 2.67 & 2.72 \\
\hline PJ & 7 & 8 & 4 & 1 & 57.14 & 12.50 & 1.43 & 2.13 \\
\hline PQ & 2 & 0 & 1 & 0 & 50.00 & & 2.00 & \\
\hline $\mathrm{JC} \& \mathrm{~J}$ & 5 & 11 & 1 & 3 & 20.00 & 27.27 & 2.20 & 2.09 \\
\hline CCJLS & 2 & 4 & 2 & 3 & 100.00 & 75.00 & 1.00 & 1.25 \\
\hline PS & 15 & 21 & 9 & 13 & 60.00 & 61.90 & 1.47 & 1.48 \\
\hline IJOTCC & 7 & 12 & 2 & 3 & 28.57 & 25.00 & 1.86 & 2.67 \\
\hline All & 268 & 420 & 182 & 145 & 67.91 & 34.52 & 1.50 & 2.19 \\
\hline
\end{tabular}

Note $. \mathrm{CRIM}=$ Criminology; JQ = Justice Quarterly; JRCD = Journal of Research in Crime and Delinquency; LSR = Law and Society Review; $\mathrm{JCLC}=$ Journal of Criminal Law and Criminology; $\mathrm{CD}=$ Crime and Delinquency; $\mathrm{CPP}=$ Criminology and Public Policy; JQC = Journal of Quantitative Criminology; $\mathrm{TC}=$ Theoretical Criminology; $\mathrm{CJB}=$ Criminal Justice and Behavior $; \mathrm{JCJ}=$ Journal of Criminal Justice $; \mathrm{YVJJ}=$ Youth Violence and Juvenile Justice; JIV = Journal of Interpersonal Violence; PJ = Prison Journal $; \mathrm{PQ}=$ Police Quarterly; AJCJ = American Journal of Criminal Justice; JC\&J = Journal of Crime and Justice; CCJLS = Criminology, Criminal Justice, Law \& Society (formerly Western Criminology Review); PS = Punishment \& Society; IJOTCC = International Journal of Offender Therapy and Comparative Criminology.

${ }^{\text {a }}$ Data on number of legal articles and courts and sentencing articles per journal taken from Rowe, McCann, \& Hemmens (2016), Table 3, p. 12. 


\section{Table 3}

Number of unique authors who authored at various frequencies (numbers of articles) in each authorship position by article type (legal articles versus courts and sentencing articles).

\begin{tabular}{|c|c|c|c|c|c|c|c|c|}
\hline \multirow[b]{2}{*}{$\begin{array}{l}\text { No. of } \\
\text { articles }\end{array}$} & \multicolumn{4}{|c|}{ Legal articles } & \multicolumn{4}{|c|}{ Courts and sentencing articles } \\
\hline & $\begin{array}{l}\text { Lead/sole } \\
\text { author }\end{array}$ & $\begin{array}{c}\text { Subsequent } \\
\text { author }\end{array}$ & $\begin{array}{c}\text { Both } \\
\text { lead/sole } \\
\text { and } \\
\text { subsequent } \\
\text { combined }^{\mathrm{a}}\end{array}$ & $\begin{array}{c}\text { Total } \\
\text { articles, } \\
\text { regardless } \\
\text { of } \\
\text { position }^{b}\end{array}$ & $\begin{array}{l}\text { Lead/sole } \\
\text { author }\end{array}$ & $\begin{array}{c}\text { Subsequent } \\
\text { author }\end{array}$ & $\begin{array}{c}\text { Both } \\
\text { lead/sole } \\
\text { and } \\
\text { subsequent } \\
\text { combined }^{\mathrm{a}}\end{array}$ & $\begin{array}{l}\text { Total } \\
\text { articles, } \\
\text { regardless } \\
\text { of } \\
\text { position }^{b}\end{array}$ \\
\hline Three & 1 & 2 & 0 & 3 & 11 & 11 & 15 & 29 \\
\hline Two & 7 & 3 & 10 & 20 & 30 & 40 & 27 & 76 \\
\hline One & 251 & 123 & 0 & 354 & 267 & 335 & 0 & 526 \\
\hline
\end{tabular}

${ }^{a}$ Does not include authors who authored this article type in only one author position (either lead/sole author or subsequent author). Gives count of unique authors who authored this article type in both author positions (lead/sole and subsequent) at each frequency (per row labels) based on combination of their lead/sole authored and subsequent authored articles of this type. ${ }^{b}$ Gives count of unique authors who authored this article type at each frequency (per row labels) based on overall number of articles of this type (regardless of author position). 
Table 4

Most Prolific Authors of Legal Articles by Authorship Position

\begin{tabular}{|c|c|c|c|c|c|}
\hline \multicolumn{2}{|c|}{ Lead/sole author } & \multicolumn{2}{|c|}{ Subsequent author } & \multicolumn{2}{|c|}{ Any author position } \\
\hline Author name & $\begin{array}{l}\text { No. of } \\
\text { articles }\end{array}$ & Author name & $\begin{array}{l}\text { No. of } \\
\text { articles }\end{array}$ & Author name & $\begin{array}{c}\text { No. of } \\
\text { articles }\end{array}$ \\
\hline Kit Kinports & 3 & Bruce A. Arrigo & 3 & Bruce A. Arrigo & 3 \\
\hline Benjamin Steiner & 2 & Michael S. Vaughn & 3 & Kit Kinports & 3 \\
\hline Christopher E. Smith & 2 & John M. Stogner & 2 & Michael S. Vaughn & 3 \\
\hline Hong $\mathrm{Lu}$ & 2 & Kristin M. Curtis & 2 & Benjamin Steiner & 2 \\
\hline Jack E. Call & 2 & Lisa Stolzenberg & 2 & Bryan Lee Miller $^{\mathrm{a}}$ & 2 \\
\hline Michelle M. Meloy & 2 & & & Christopher E. Smith & 2 \\
\hline Stephen J. Morse & 2 & & & Craig Hemmens $^{\mathrm{a}}$ & 2 \\
\hline William W. Berry & 2 & & & Elena Larrauri Pijoan ${ }^{a}$ & 2 \\
\hline & & & & Hong Lu & 2 \\
\hline & & & & Jack E. Call & 2 \\
\hline & & & & Jamie L. Flexon ${ }^{\mathrm{a}}$ & 2 \\
\hline & & & & Jeffrey T. Walker ${ }^{\mathrm{a}}$ & 2 \\
\hline & & & & John K. Cochran ${ }^{\text {a }}$ & 2 \\
\hline & & & & John M. Stogner & 2 \\
\hline & & & & Kristin M. Curtis & 2 \\
\hline & & & & Lening Zhang ${ }^{\mathrm{a}}$ & 2 \\
\hline & & & & Lisa Stolzenberg & 2 \\
\hline & & & & Michelle M. Meloy & 2 \\
\hline & & & & Mitchell B. Chamlin ${ }^{\mathrm{a}}$ & 2 \\
\hline & & & & Shaun L. Gabbidon ${ }^{\mathrm{a}}$ & 2 \\
\hline & & & & Stephen J. Morse & 2 \\
\hline & & & & Stewart J. D'Alessio ${ }^{\mathrm{a}}$ & 2 \\
\hline & & & & William W. Berry & 2 \\
\hline
\end{tabular}

Note. For each authorship position category (lead/sole, subsequent, or any), authors who authored more than one legal article in that authorship position category are included. ${ }^{a}$ Authored legal articles in both lead/sole and subsequent position. Some of these authors may not appear in the columns for the other authorship position categories (lead/sole, subsequent) because they did not exceed the threshold (more than one legal article) for that authorship position category. 
Table 5

Most Prolific Authors of Courts and Sentencing Articles by Authorship Position

\begin{tabular}{|c|c|c|c|c|c|}
\hline \multicolumn{2}{|c|}{ Lead/sole author } & \multicolumn{2}{|c|}{ Subsequent author } & \multicolumn{2}{|c|}{ Any author position } \\
\hline Author name & $\begin{array}{l}\text { No. of } \\
\text { articles }\end{array}$ & Author name & $\begin{array}{l}\text { No. of } \\
\text { articles }\end{array}$ & Author name & $\begin{array}{l}\text { No. of } \\
\text { articles }\end{array}$ \\
\hline Brian D. Johnson & 9 & Cassia Spohn & 10 & Cassia Spohn $^{\mathrm{a}}$ & 14 \\
\hline John Wooldredge & 9 & William Bales & 8 & Brian D. Johnson $^{a}$ & 13 \\
\hline Michael J. Leiber & 8 & Marc Gertz & 5 & John Wooldredge $^{\mathrm{a}}$ & 12 \\
\hline Jeffrey T. Ulmer & 6 & Brian D. Johnson & 4 & Michael J. Leiber ${ }^{\mathrm{a}}$ & 10 \\
\hline Shawn D. Bushway & 6 & Daniel P. Mears & 4 & William Bales $^{\mathrm{a}}$ & 10 \\
\hline Richard D. Hartley & 5 & James Frank & 4 & Jeffrey T. Ulmer ${ }^{\mathrm{a}}$ & 8 \\
\hline Travis W. Franklin & 5 & John H. Kramer & 4 & Richard D. Hartley ${ }^{\mathrm{a}}$ & 8 \\
\hline Cassia Spohn & 4 & Julie L. Dempsey & 4 & Daniel P. Mears ${ }^{\mathrm{a}}$ & 7 \\
\hline Nancy Rodriguez & 4 & M. Dwayne Smith & 4 & Shawn D. Bushway ${ }^{a}$ & 7 \\
\hline Tina L. Freiburger & 4 & Sondra J. Fogel & 4 & Nancy Rodriguez ${ }^{\mathrm{a}}$ & 6 \\
\hline Benjamin Steiner & 3 & Beth Bjerregaard & 3 & Marc Gertz & 5 \\
\hline Bin Liang & 3 & David L. Myers & 3 & Tina L. Freiburger ${ }^{a}$ & 5 \\
\hline Daniel P. Mears & 3 & Duane C. McBride & 3 & Travis W. Franklin & 5 \\
\hline Joanna D. Pozzulo & 3 & Jeffrey T. Walker & 3 & Beth Bjerregaard ${ }^{\mathrm{a}}$ & 4 \\
\hline John D. Burrow & 3 & John Wooldredge & 3 & David L. Myers $^{\mathrm{a}}$ & 4 \\
\hline Kareem L. Jordan & 3 & Joseph Johnson & 3 & James Frank & 4 \\
\hline Kelly Hannah-Moffat & 3 & Richard D. Hartley & 3 & Joanna D. Pozzulo $^{a}$ & 4 \\
\hline Marian R. Williams & 3 & Rodney L. Engen & 3 & John D. Burrow ${ }^{\mathrm{a}}$ & 4 \\
\hline $\begin{array}{l}\text { Stacy Hoskins } \\
\text { Haynes }\end{array}$ & 3 & Stephen Demuth & 3 & John H. Kramer & 4 \\
\hline Xia Wang & 3 & Steven Belenko & 3 & Julie L. Dempsey & 4 \\
\hline \multirow[t]{13}{*}{$\begin{array}{l}\text { Yvonne M. Terry- } \\
\text { McElrath }\end{array}$} & 3 & Ted Chiricos & 3 & M. Dwayne Smith & 4 \\
\hline & & & & Sondra J. Fogel & 4 \\
\hline & & & & Ted Chiricos ${ }^{\mathrm{a}}$ & 4 \\
\hline & & & & Timothy Griffin $^{\mathrm{a}}$ & 4 \\
\hline & & & & Allison D. Redlich ${ }^{\mathrm{a}}$ & 3 \\
\hline & & & & Anne Morrison Piehl ${ }^{\mathrm{a}}$ & 3 \\
\hline & & & & Barry Ruback $^{\mathrm{a}}$ & 3 \\
\hline & & & & Benjamin Steiner & 3 \\
\hline & & & & Bin Liang & 3 \\
\hline & & & & Duane C. McBride & 3 \\
\hline & & & & Evelyn M. Maeder ${ }^{a}$ & 3 \\
\hline & & & & Jeffrey T. Walker & 3 \\
\hline & & & & Jennifer H. Peck ${ }^{\mathrm{a}}$ & 3 \\
\hline
\end{tabular}




\begin{tabular}{|c|c|c|c|c|c|}
\hline \multicolumn{2}{|c|}{ Lead/sole author } & \multicolumn{2}{|c|}{ Subsequent author } & \multicolumn{2}{|c|}{ Any author position } \\
\hline Author name & $\begin{array}{l}\text { No. of } \\
\text { articles }\end{array}$ & Author name & $\begin{array}{l}\text { No. of } \\
\text { articles }\end{array}$ & Author name & $\begin{array}{l}\text { No. of } \\
\text { articles }\end{array}$ \\
\hline & & & & $\begin{array}{l}\text { Johnathan M. } \\
\text { Golding }^{\mathrm{a}}\end{array}$ & 3 \\
\hline & & & & Joseph Johnson & 3 \\
\hline & & & & Joshua C. Cochran ${ }^{a}$ & 3 \\
\hline & & & & Kareem L. Jordan & 3 \\
\hline & & & & Kelly Hannah-Moffat & 3 \\
\hline & & & & Marian R. Williams & 3 \\
\hline & & & & Megan Kurlychek $^{\mathrm{a}}$ & 3 \\
\hline & & & & Michael T. Light ${ }^{\mathrm{a}}$ & 3 \\
\hline & & & & Mona Lynch ${ }^{\mathrm{a}}$ & 3 \\
\hline & & & & Noelle E. Fearn ${ }^{\mathrm{a}}$ & 3 \\
\hline & & & & Rob Tillyer ${ }^{\mathrm{a}}$ & 3 \\
\hline & & & & Rodney L. Engen & 3 \\
\hline & & & & Scott R. Maggard ${ }^{\mathrm{a}}$ & 3 \\
\hline & & & & Sean Maddan $^{\mathrm{a}}$ & 3 \\
\hline & & & & $\begin{array}{l}\text { Stacy Hoskins } \\
\text { Haynes }\end{array}$ & 3 \\
\hline & & & & Stephen Demuth & 3 \\
\hline & & & & Steven Belenko & 3 \\
\hline & & & & Tara N. Richards ${ }^{\mathrm{a}}$ & 3 \\
\hline & & & & Xia Wang & 3 \\
\hline & & & & $\begin{array}{l}\text { Yvonne M. Terry- } \\
\text { McElrath }\end{array}$ & 3 \\
\hline
\end{tabular}

Note. For each authorship position category (lead/sole, subsequent, or any), authors who authored more than two courts and sentencing article in that authorship position category are included.

${ }^{a}$ Authored courts and sentencing articles in both lead/sole and subsequent position. Some of these authors may not appear in the columns for the other authorship position categories (lead/sole, subsequent) because they did not exceed the threshold (more than two courts and sentencing articles) for that authorship position category. 


\section{Figures}

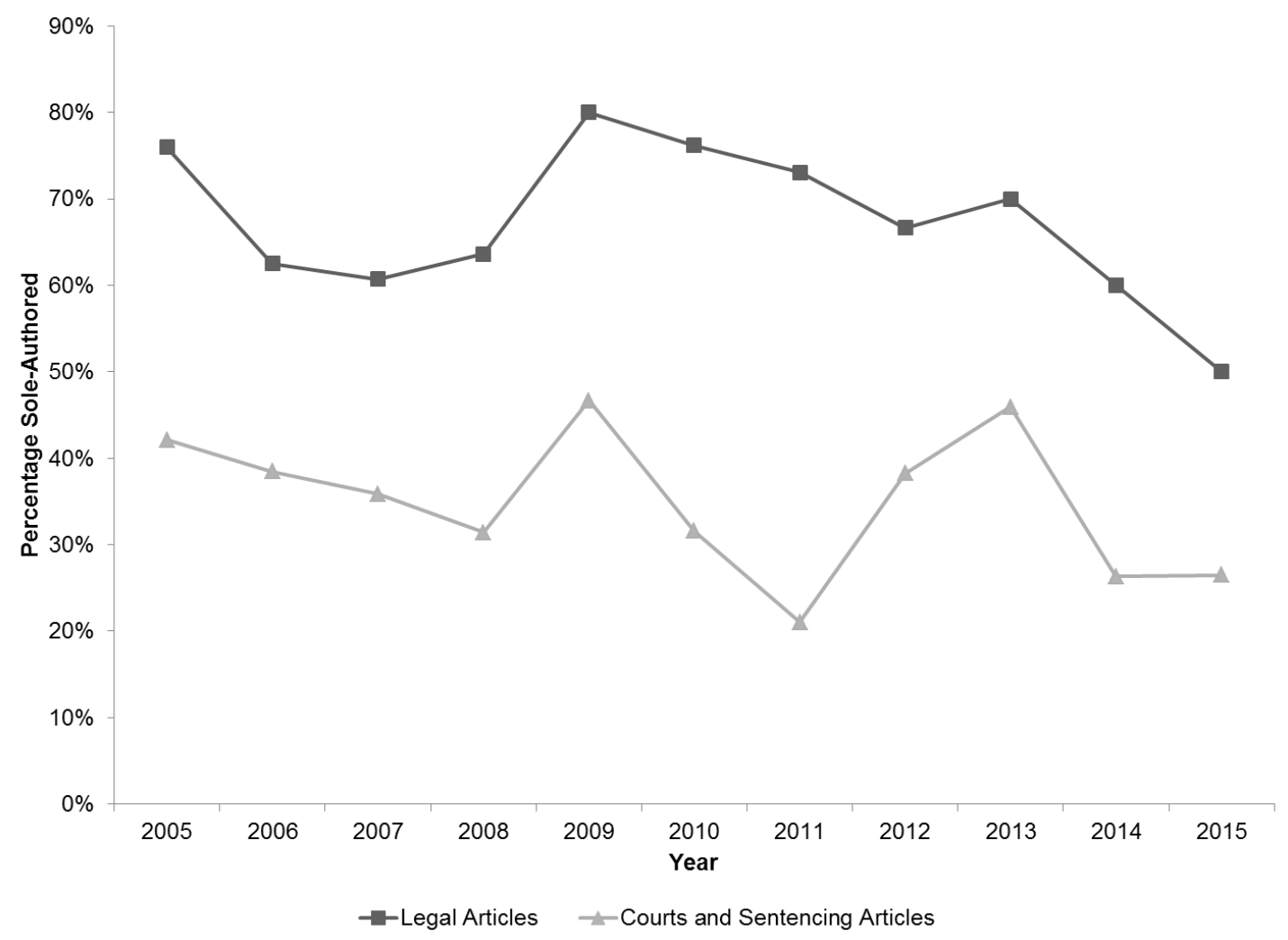

Figure 1. Trend in percentage of legal articles which are sole-authored and percentage of courts and sentencing articles which are sole-authored over time. 


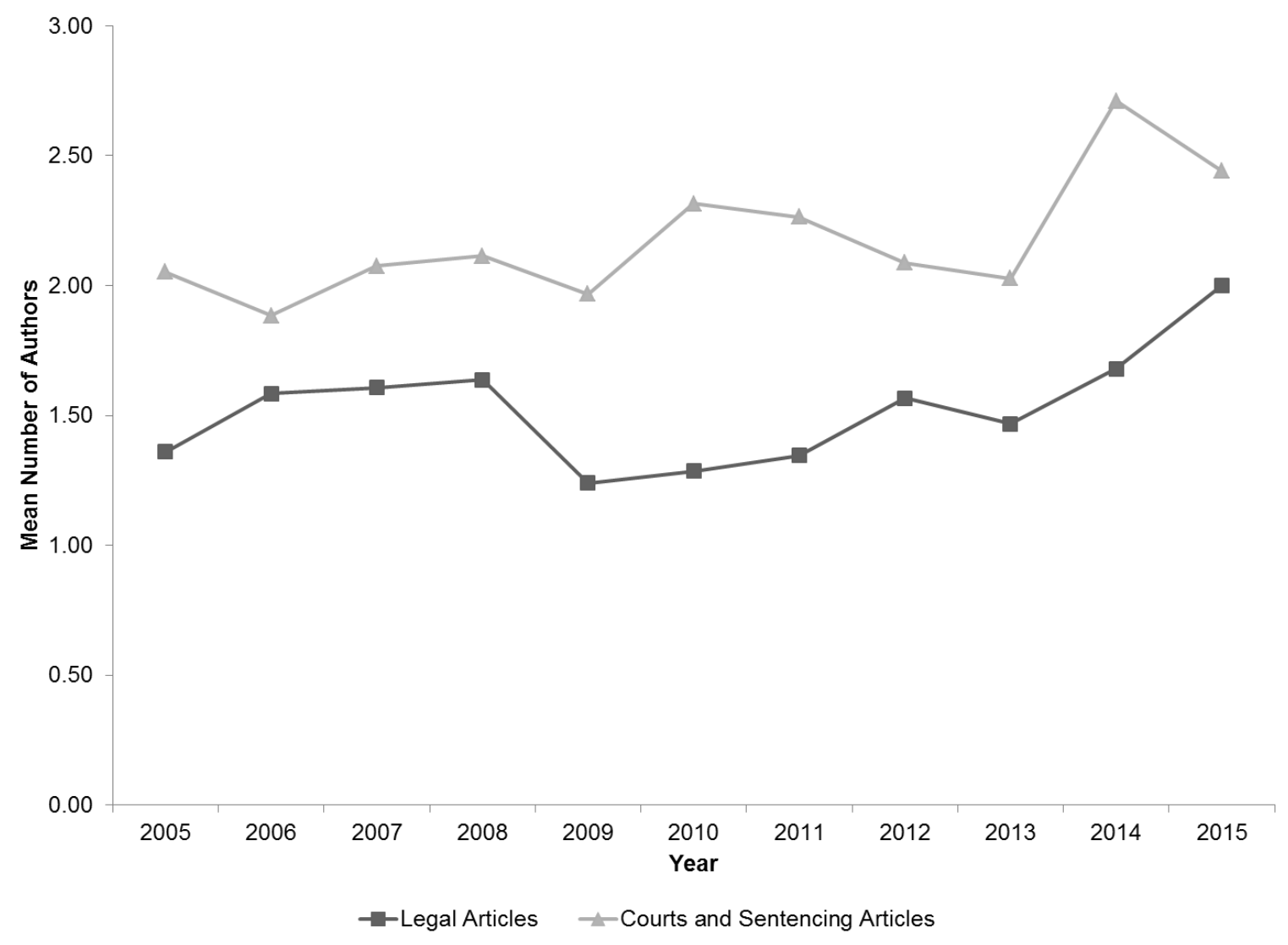

Figure 2. Trends in mean number of authors for legal articles and mean number of authors for courts and sentencing articles over time. 


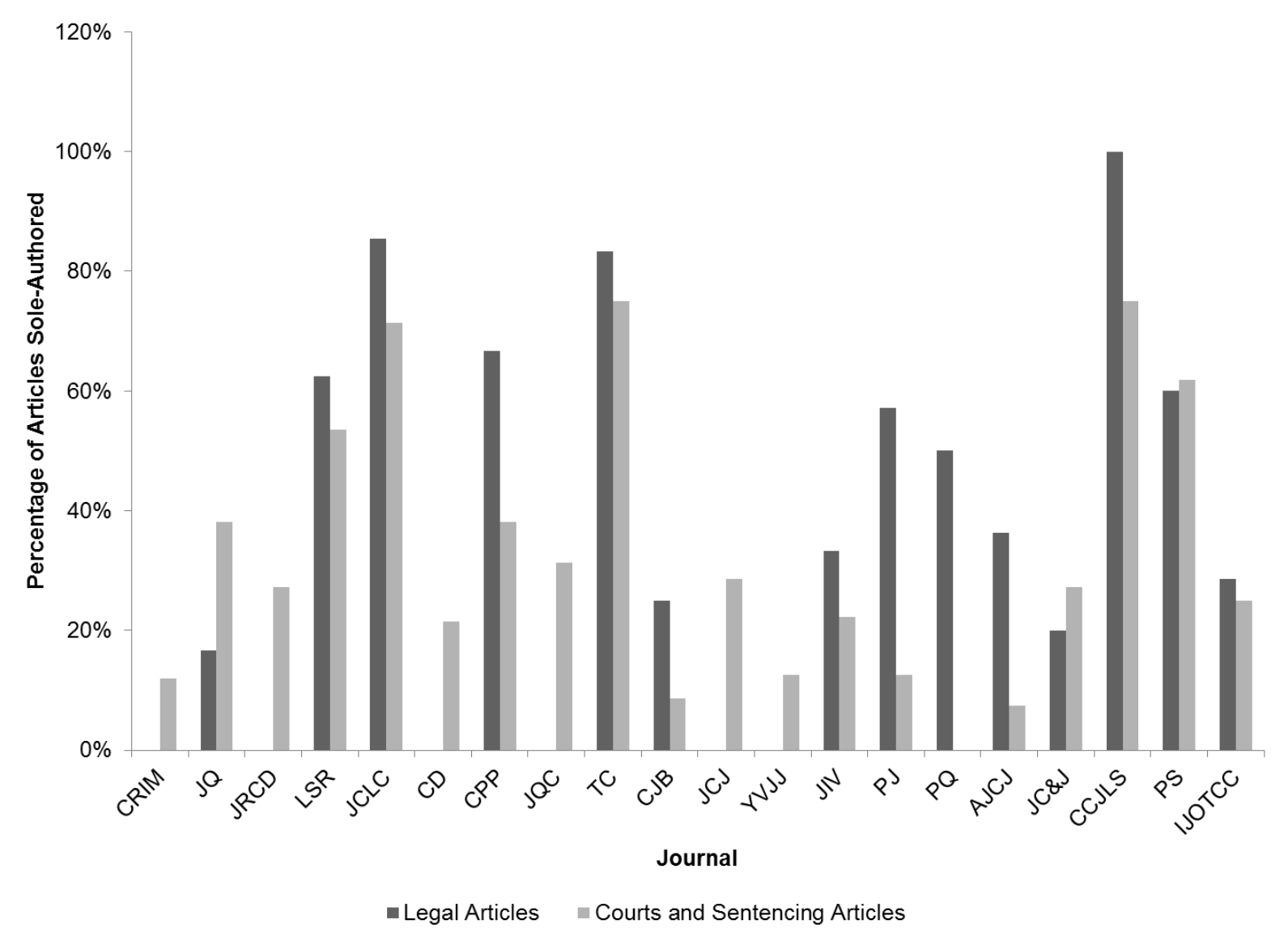

Figure 3. Comparison of percentage of legal articles which are sole-authored and percentage of courts and sentencing articles which are sole-authored by journal. CRIM = Criminology; JQ = Justice Quarterly; JRCD = Journal of Research in Crime and Delinquency; LSR = Law and Society Review; JCLC $=$ Journal of Criminal Law and Criminology; $\mathrm{CD}=$ Crime and Delinquency; CPP $=$ Criminology and Public Policy; JQC $=$ Journal of Quantitative Criminology $; \mathrm{TC}=$ Theoretical Criminology $; \mathrm{CJB}=$ Criminal Justice and Behavior; JCJ $=$ Journal of Criminal Justice; YVJJ = Youth Violence and Juvenile Justice; JIV = Journal of Interpersonal Violence; PJ = Prison Journal; PQ = Police Quarterly; AJCJ = American Journal of Criminal Justice; JC\&J = Journal of Crime and Justice; CCJLS = Criminology, Criminal Justice, Law \& Society (formerly Western Criminology Review); PS = Punishment \& Society; IJOTCC = International Journal of Offender Therapy and Comparative Criminology. 


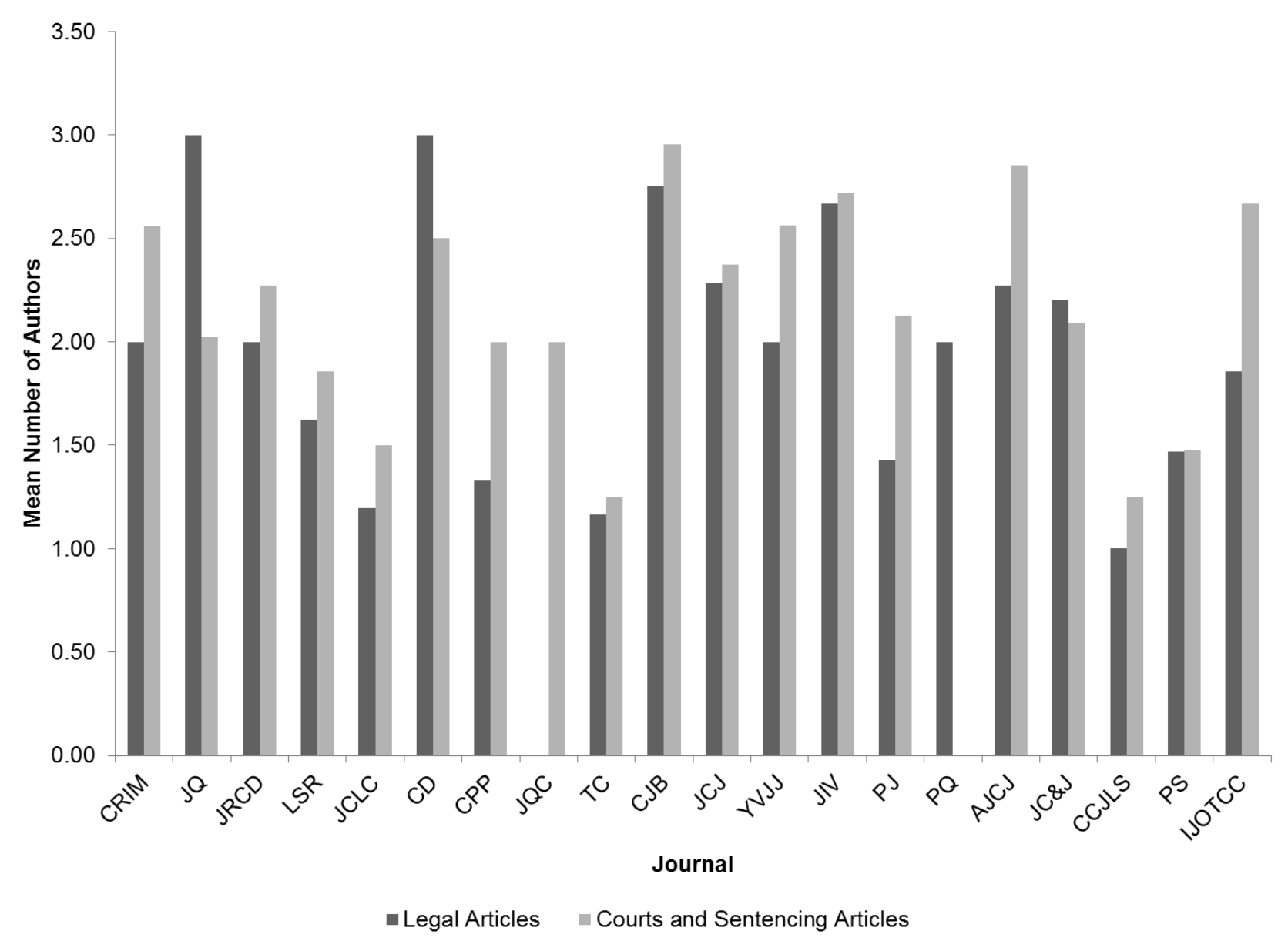

Figure 4. Comparison of mean number of authors for legal articles and mean number of authors for courts and sentencing articles by journal. CRIM = Criminology; JQ = Justice Quarterly; JRCD = Journal of Research in Crime and Delinquency; LSR = Law and Society Review; JCLC $=$ Journal of Criminal Law and Criminology; $\mathrm{CD}=$ Crime and Delinquency; $\mathrm{CPP}=$ Criminology and Public Policy; JQC = Journal of Quantitative Criminology; TC = Theoretical Criminology; $\mathrm{CJB}=$ Criminal Justice and Behavior $; \mathrm{JCJ}=$ Journal of Criminal Justice; YVJJ = Youth Violence and Juvenile Justice; JIV = Journal of Interpersonal Violence; PJ = Prison Journal; PQ $=$ Police Quarterly; AJCJ = American Journal of Criminal Justice; JC\&J = Journal of Crime and Justice; CCJLS = Criminology, Criminal Justice, Law \& Society (formerly Western Criminology Review); PS = Punishment \& Society; IJOTCC = International Journal of Offender Therapy and Comparative Criminology. 